\title{
Discourses of un/employment in Europe: The Austrian case
}

\author{
RUTH WODAK and THEO VAN LEEUWEN
}

\section{Abstract}

This article deals with the discursive construction of unemployment in Austria, through an analysis of speeches by former Chancellor Klima and reports in the Austrian press. It is a companion to an earlier paper investigating the same issues in the UK. Both deal with left-wing governments who, in the European context, are proposing economic change and developing and adapting a range of legitimation devices and rhetorical strategies to this end. There are clear similarities, which can be traced back to European policies, but there are also local accents. In the UK there is a greater emphasis on economic issues and 'moral underclass' discourse, while in Austria there is more emphasis on political-cum-ideological issues.

Keywords: critical discourse analysis; comparative study of Austria and UK; social actor analysis; discourse-historical approach; political discourse; rhetorical strategies; youth un/employment.

\section{Introduction: European un/employment discourse ${ }^{1}$}

In 1998 no fewer than 18 million people were unemployed in the member states of the European Union, a rate of ten-and-a-half percent according to the International Labour Office (ILO) definition of the unemployment rate. This defines as unemployed all those aged 15 years and over who 'are without work, are available to start work within the next two weeks, and have actively sought employment at some time during the previous four weeks' (Joint Employment Report 1998). ${ }^{2}$

There are clear indicators that Europe is moving towards the 'American direction', reducing (or, more neutrally speaking, 'changing') social welfare systems, minimum wages, unemployment assistance, labor market regulations, union powers, and so on. The politics of 'flexibility' are 
apparently also beginning to dominate the EU political arena (see Sennett 1998). Consider Thurow's interpretation:

While no official wants to say it loud, 'flexibility' is simply a code word for 'falling wages'. If 'flexibility' were to occur, there is every reason to believe that the European wage structure would move rather rapidly toward the American pattern. When the United Kingdom abolished its Wage Councils, 40 per cent of the work force ended up working below the old minimum wages. (Thurow 1996: 39)

According to Thurow, Europe seems to be caught in the dilemma of either keeping social standards high and at the same time accepting high unemployment, or Americanizing the labor markets, i.e., deregulating them in order to create 'flexible' jobs, with the consequence of falling wages and rising income inequality.

'Flexibility' is meant to be one of the answers to 'globalization', which, itself, is viewed as a natural phenomenon all countries have to confront and cope with, as something which some experts view as a cause of insecurity (Bauman 1999) and others as a positive development. Our studies on expert committees (Wodak 2000a; 2000b) have illustrated the attempts to understand, explain, define, and recontextualize globalization phenomena. The arguments which turned up in debates can be summarized as follows:

1. globalization is linked to unemployment;

2. this link is contradicted;

3. the positive aspects of globalization are emphasized and commonsense beliefs are contradicted;

4. European 'mistakes' are pointed out;

5. the specific European ideals remain untouched;

6. these ideals guarantee Europe a strong position in the world market;

7. necessity of change is underlined,

8. because Europe's position in the world market would otherwise weaken.

The main persuasive goal therefore, if one takes up this argumentative chain, is understanding the link between unemployment, globalization, and economic strength, with competition and flexibility as the main instruments with which to reach the goal of reduced unemployment. At the same time, a second aim is exposed: to construct a specifically European way, a specific European adaptation to globalization and a new European identity (see Weiss and Wodak 2000a,b).

Accordingly, in December 1993, Jacques Delors, at that time president of the European Commission, presented the White Paper 'Growth, Competitiveness, Employment' to the heads of member state 
governments at the European Council summit in Brussels (European Commission 1994). As the title suggests, this paper focused on economic growth and competitiveness as necessary preconditions for higher employment rates. The central idea can be summed up as follows: higher competitiveness leads to more growth and more growth leads to more employment. The magic formula was 'employment-intensive growth' (European Commission 1994: 139-140).

Concerning the so-called 'active' labor market policy, the White Paper put emphasis on the 'adaptation of education and vocational training'on 'life-long learning' and 'training policies' - and on the 'flexibility of work' (European Commission 1994: 133-134). Consequently, 'structural' measures for increasing competitiveness primarily referred to structural changes in the labor markets: employment policy was, to a large extent, seen as labor market policy. As a whole, the White Paper represented the mixture of globalization, competitiveness, and flexibility discourse typical of the neoliberal commonsense economic theories of the early 1990s.

The next step in the development of a coordinated European Union policy on employment was the European Council meeting in Essen 1994. In order to continue and strengthen the strategies of the White Paper, the Presidency Conclusions from the Essen summit mentioned five 'key areas' for increasing employment. (As will be seen, these have been reinterpreted in the local policies of member states in various ways.)

1. Promoting investment in vocational training.

2. Increasing the employment intensiveness of growth.

3. Reducing non-wage labor costs.

4. Improving the effectiveness of labor market policies.

5. Improving measures to help groups that are particularly hard hit by unemployment.

The Essen catalog thus continued the 'program' of the White Paper. The 'employment-intensiveness of growth' remained the main focus; and the flexibility discourse remained the main argumentative frame.

The European Council summits in Madrid (December 1995), Florence (June 1996), and Dublin (December 1996) followed the idea of the Essen process - each time on the basis of a joint report prepared by the European Council and Council of Ministers (CM) (Economics and Finances [ECOFIN] and Social Affairs). Additionally, in 1996, Jacques Santer, Jacques Delors' successor as president of the council, presented a 'confidence pact', the promotion of a European Union-wide 'fight' against unemployment. The document brought nothing new, it merely psychologized the problem. Santer suggested that the labor market situation could only be improved by establishing a 'climate of confidence' 
between all economic and political participants at supranational, national, and local levels so that investment and demand would get going again. In the face of absent legal obligations, psychological issues like confidence, trust, and belief were emphasized. ${ }^{3}$ In 1997, however, the Amsterdam treaty finally institutionalized the Essen process in a new title on employment.

The Amsterdam Treaty, signed on 2 October 1997, represented a further step in EU integration, particularly with regard to employment policy. For the first time, employment was included as a separate title into a Community/Union treaty. With the adoption of the employment title, the member states 'agreed that employment should be considered as a matter of common concern'. The treaty 'reinforces the coordination of national employment policies and foresees the establishment of common guidelines which can in due course lead to recommendations to Member States' (European Commission 1997: 1).

With respect to general decision-making procedures, the treaty extended the co-decision competencies of the European Parliament in policy areas such as employment creation, equal opportunity, public health, transparency, and data protection. A new title on the free movement of persons, asylum, and immigration was also included in the new treaty, although the UK, Ireland, and Denmark have opted out of these provisions. However, following the decision of the UK to opt into the social protocol agreed at Maastricht, this title was now included in the main body of the treaty.

Our study on discourses on un/employment in the EU (Muntigl et al. 2000) summarized all these developments by analyzing the Council of Luxemburg (November 1997) and the decision-making processes involved in preparing for this specific council. It established, first of all, that globalization rhetoric functions to enable politicians and bureaucrats to propose changes in employment policies by reifying and naturalizing globalization, thus providing arguments which make change appear inevitable and necessary (see Weiss 2000a; Wodak 2000a, 2000b). We employed the phrase globalization rhetoric to refer to the discursive construction of a state of affairs known as 'globalization' that exists in a very close argumental relationship to other constitutive elements of EU employment discourse: e.g., competitiveness, location, and flexibility. The 'need' for competitiveness and liberalization as a precondition for employment growth is substantiated by the globalization rhetoric - and this is true for both macroeconomic and structural measures. Moreover such rhetoric is invoked to proclaim a European identity distinct from other 'global players', particularly the USA and Japan. Trade unions and employers view globalization and the impact of globalization on 
unemployment very differently: the employer side is convinced of the inevitability of globalization processes in the economy and proposes to adapt the European nation states to the new demands of the market. They emphasize competitiveness. Thus flexibility, new labor laws, and less state intervention (among other things) are proposed. Globalization is not questioned, but appears as presupposition to all economic concepts. Secondly, globalization rhetoric legitimizes profound changes in European economic policies, justifying them as a specific 'European way' of fighting unemployment (see Straehle et al. 1999; Wodak, in print). Finally, these arguments then serve to construct a European identity, different to that of the USA and Japan. In other words, they also possess identity-constructing functions (Billig 1997; Wodak et al. 1999).

\section{Methodology}

In this article we will present a case study of the way such economic proposals and debates are implemented at a national level in Austria. The study explicitly complements an earlier case study of unemployment discourses in the UK (van Leeuwen 1999). Comparing UK and Austrian unemployment discourses will demonstrate their common links with EU-level discourses as well as show up the specific local accents they acquire in different national contexts. It should be noted that the Austrian political speeches and other texts we analyze are data from before the most recent political developments in Austria, where, since its installment on 4 February 2000, a new right-wing government now proceeds in a directly neoliberal manner.

The principal methods of analysis used in the two studies are summarized in the following.

\section{Social actor analysis}

Social actor analysis is concerned with the ways in which social actors are represented in discourse. A detailed framework is presented in van Leeuwen (1996). Here we use the following categories from this framework. Firstly, social actors may be deleted, for instance through passive agent deletion through the circumstantialization of agency (as in examples like Demonstrators died in clashes with police). When social actors are not deleted, reference to them may be personalized or impersonalized. Impersonal reference includes institutionalization, where an institution rather than a person fills the actor role (as in examples like The Government took measures ...), instrumentalization, where the instrument of an action rather than the actor fills the actor role (as in examples like 
The measures sought to diminish ...), and utterance autonomization, where the utterance rather than the utterer fills the actor role (as in examples like 'His speech said ...). Personalization includes nomination, where the actor is referred to by name (e.g., Mr. Browne said ...), functionalization, where the actor is referred to in terms of a role or function (e.g., The Chancellor said ...), and categorization, where the actor is referred to by means of a term indicating a category which in the given context is held to be permanent, such as gender, age, or race. The choice between such alternatives almost invariably plays a highly significant role in the ideological construction of political discourse.

\section{Legitimation}

Our analysis of legitimation follows the principles set out in van Leeuwen and Wodak (1999). To summarize briefly, the principal types of legitimation are authorization, rationalization, moralization, and 'mythopoiesis'. In the case of authorization, legitimation is by appeal to some kind of authority, whether personal or otherwise ('tradition', 'the majority', 'expert knowledge', and 'role models' can also function as sources of authority). Rationalization is legitimation by appeal to purposes and explicit theories. In the material we analyzed this often takes the form of small nuggets of wisdom such as Unemployment is a deep-seated structural weakness which undermines the great economic strength of our country or Unemployment blights people's lives. Such ideas are then used to legitimize or delegitimize action. Legitimation as moralization takes the form of references to actions (e.g., in this case, 'work', 'being unemployed', etc.) by means of abstract terms or expressions, as when making a contribution to Britain, or achieving your potential stands for 'being employed'. It also includes negative values, as when stay at home is used for 'being unemployed'. In the case of 'mythopoiesis', legitimation occurs through the telling of stories which serve as moral exemplars or cautionary tales.

\section{Taxonomies}

A given broader category of social actors may, in a given discursive context, be referred to in a number of more specific categories. The UK Budget Speech we analyzed, for instance, created a number of types of 'long-term unemployed', including 'those on long-term benefits', 'men and women who have been unemployed for two years or more', 'long-term unemployed adults', and so on. A method devised by Martin (1992) can bring out the implicit taxonomies which are created in this way. When the implicit taxonomies of different texts (e.g., different newspapers reporting 
the same Budget Speech) are compared, they turn out to be different in ways that clearly reflect the newspaper's stance - a newspaper taking the line that people are abusing welfare will elaborate a taxonomy of 'people abusing the dole', a newspaper taking a 'social exclusion' line will elaborate categories of 'socially excluded', and so on.

Finally we have, in this present article, also drawn on Fairclough's analysis of the language of New Labour (2000), as this analysis is particularly helpful in identifying key themes of contemporary center-left welfare discourses.

\section{New labour un/employment discourses}

To allow close comparison between the two case studies we have so far produced, we will summarize our previous study at some length. In his 1998 Budget Speech, Chancellor Gordon Brown announced the abolition of the national unemployment insurance system and the take over of its functions by the Taxation Office, in the form of a 'tax and benefits' system. Everyone capable of working would either have an 'offer of training' (or of counseling) or an 'offer of work'. In other words, there would be no unemployed, there would only be people in work and people in the process of 'moving from welfare to work'. The offers of work would of course have to come from employers, and here the Government announced several incentives for employers to hire more people, on low to very low wages. First of all, there would be a tax credit to supplement these wages. Secondly, the added costs of labor (insurance) were decreased - the more so the lower the wage. Thirdly, the Government pledged to provide 70 percent of childcare costs for people receiving these low wages. In other words, certain minimum subsistence conditions would be guaranteed; employers would be freed from the necessity to pay a decent wage and look after their employees' interests; employees would receive combined (low) wages and benefits; and taxpayers, though paying just as much as before, would be assured that their taxes did not go towards 'welfare' for 'dole scroungers' (instead they went, of course, to the employers). Several of the key points of the Essen summit can be recognized here: an emphasis on vocational training, reduction in non-wage labor costs and measures to help particularly hard hit groups.

The paper then analyzed how the three parties involved (government, employer, and employee) and their roles in the processes of ensuring employment and insuring unemployment were represented, both by the Government itself (through an analysis of the relevant sections of the Budget Speech) and by the media (through an analysis of their coverage of the Budget Speech). The paper also looked at the way work was 
legitimized in these texts (and unemployment delegitimized). Both tabloid and broadsheet papers were included. The principal findings are summarized in the following.

The Budget Speech instrumentalized and institutionalized the Government's role. In other words, the Government's actions were described impersonally, as the actions of 'the Budget', 'the tax and benefits system' and so on - a large vocabulary of such terms was used. Employers' actions, on the other hand, were not instrumentalized or institutionalized, but simply described as the actions of people, of 'employers' or 'companies'. As for the unemployed, they were divided into no less than eleven different types, such as 'long term unemployed adults', 'young people looking for a first step on the ladder of employment', 'lone parents who want to work', and so on. Specific measures were proposed for each of these groups.

In reporting the speech, the newspapers took a different tack and personalized the Government, representing those involved as personally responsible for the actions announced. The Times, for instance, spoke about Mr. Brown, the Chancellor, etc., rather than using instrumentalizations and institutionalizations such as the system, the Budget, and so on. The Sun, a pro-Labour paper, combined the two modes of agency (e.g., Mr. Brown's tax system). In referring to the unemployed, the papers did not use the elaborate taxonomy set up in the Budget Speech, but created their own simpler ones, in order to legitimize the Government's actions in their own ways. The Guardian, for instance, distinguished several kinds of 'poor families', thus using an 'old Labour' welfare discourse (New Labour prefers the term social exclusion over poverty, cf. Fairclough 2000), and the Sun distinguished unemployed 'who want to work' and unemployed 'who don't want to work', constructing the Government's policies as a tough 'send them back to work' program, under the headline 'Hi-ho, hi-ho, it's off to work we go'.

The Government's role in all this was constructed as that of a 'manager'. Causative constructions such as Mr. Brown's Budget included coaxing bosses to take on more staff and The Budget aims at helping the long-term unemployed find work represented 'taking on staff' as done by the employers and 'finding work' as done by the unemployed, but only because the Government is behind them, coaxing and spurring on both employers and unemployed like a sports manager at the sidelines. Any 'nonmanaged' actions tended to be much less active in nature, for instance receive benefits, stay at home, etc.

The paper finally looked at the legitimation of work. Here the Budget Speech mostly used authorization legitimation, that is, legitimation through the authority of the Government (I say to those who can 
work: 'It is your responsibility to work... You have no excuse to stay home'). It also used moralization legitimation, through various kinds of moral appeal (e.g., You should make a contribution to Britain). Unemployment was delegitimized as deviant behavior (e.g., laziness) and in terms of social exclusion. There were also various rationalizations, such as the already quoted expressions Unemployment is a deep-seated structural weakness and Unemployment blights people's lives.

The newspapers, too, relied mostly on authorization legitimation (e.g., 'The stay at home culture is over', said Mr. Brown) and moralization legitimation (e.g., Families need no longer be dependent), and they delegitimized the old welfare system as creating dependency and forming a burden on the taxpayer, while heaping praise on the Chancellor personally.

\section{Austrian un/employment discourses: Klima's Party Congress speech}

We shall now attempt to analyze a similar moment in the history of unemployment in Austria, a little later in the same year. Our case story here relates specifically to youth unemployment (see the proposed EU policy-making measures already discussed). A year earlier, in 1997, the Government had started what they called a Lehrlingsoffensive 'apprenticeship attack'. (We deliberately translate this aggressive metaphor literally, rather than softening it by calling it an 'apprenticeship initiative' or something along those lines.) This involved creating Lehrstellen 'apprenticeships' - which of course in fact had to be created by employers. In other words, as in Britain, the Government tried to coax employers into creating jobs through tax incentives, insurance contributions, and a reduction in the amount of red tape, of which there is a great deal in Austria. After a year it became clear that the results did not exactly add up to the desired elimination of youth unemployment. The figures vary, but our material suggests that only 1500 new apprenticeships were offered (in addition to 800 existing ones, giving a total of 2300), with something like 7300 school leavers applying for them. Although the Government labeled this first 'attack' a success, and boasted that Austria's level of youth unemployment was lower than that of any other European country, a further 'attack', a further Lehrlingsoffensive, was announced the next year, redoubling efforts to coax employers into offering apprenticeships and introducing Lehrlingsstiftungen 'apprenticeship grants/foundations' and Lehrgänge 'apprenticeship courses' to provide supplementary education which would 'prepare for apprenticeship' those young unemployed who had been unable to actually obtain an apprenticeship. In this way 
youth unemployment could appear to be eliminated. All school leavers would either have an offer of apprenticeship, or be in the process of 'preparing' for it. In addition, the Government created specific Lehrberufe 'apprentice professions' which would introduce the idea of apprenticeship into new areas.

On 30 October, as these measures were in preparation, Chancellor Klima addressed the Party Congress of the SPÖ, the Austrian Socialist Party, unfolding a new program for social democratic politics, a 'compass for the twenty-first century' and an answer from the SPÖ to the 'Deregulierungsmanie eines ungehemmten Liberalismus [deregulation mania of an unbridled neoliberalism]', rejecting both the 'neoliberales Modell eines hemmungslosen Individualismus [neoliberal model of an unrestrained individualism]' and the 'konservatives Modell einer karitativen Bürgergesellschaft [conservative model of a charity-minded bourgeois society]' in favor of a 'verantwortungsbewußten Solidargemeinschaft [solidaristic community conscious of its responsibilities]' and a 'European model of social democracy'. This speech illustrates the attempt to 'market' and legitimate new measures with traditional ideological slogans. This is to be explained by the setting itself: Klima addresses the Socialist Party, which is opposed to neoliberal policies. The genre chosen here necessarily has to be different from the Budget Speech analyzed in van Leeuwen (1999). What makes this more interesting is the fact that Klima himself is a manager by profession and thus, in terms of his background, is much more closely allied to the employers' side than to the traditional electorate of the Socialist Party. The speech therefore has to be seen as serving purely legitimatory functions. Though the language is perhaps less dominated by economical pragmatism, and couched in more political and ideological terms, the program behind it is clearly reminiscent of the politics of New Labour in the UK.

Questions of work and unemployment are central to the program: 'Arbeit steht nach wie vor an erster Stelle unserer politischen Perspektiven [As always, work is central to our political perspectives]'. It is, says Klima, unacceptable that there are still more than 20 million unemployed in Europe. As in the case of Chancellor Brown's Budget Speech, for eliminating unemployment, a policy of 'neuer Vollbeschäftigung [new full employment]' is the key. This policy is to be seen as distinctly different both from traditional forms of Government unemployment insurance ('das Verteilen von Almosen, wie immer man sie auch in liberalen Behübschungen nennen mag [the distribution of alms, whatever cosmetic euphemisms liberals may give this]') and from a cynical economic rationalism which sees 'a healthy level of unemployment' as guaranteeing a compliant workforce. 
The similarities to the discourses of New Labour (cf. Fairclough 2000) are striking. Here, too, the constant stress on 'new' ('Es geht um eine Neubewertung der Arbeit, und es geht um eine Neuaufteilung der Arbeit und der Lebensarbeitszeit [It is about a new evaluation of work and a redistribution of work and the working life]') and the constant reference to 'change' which it is useless to try and resist (even though at one stage unspecified 'barriers' are in fact said to 'obstruct the new world of work'): 'Die wirtschaftlichen Gewichte verschieben sich von der Produktion zu Dienstleistung, von starren Arbeitsformen zu flexiblen Modellen [The economic balance is shifting from production to services, and from rigid to flexible models of work]'; 'Wir können niemandem vor dem Wandel bewahren [We can shelter no one from change]'.

And yet, according to Klima it is also the aim of the program to 'actively shape change', to guide it in a direction which can be seen as 'just' and 'humane'. The key to this is, again, work. As in New Labour Britain (cf. Fairclough 2000: 59), work is construed as a fundamental human right. Although Klima acknowledges the importance of 'socially or personally useful activities such as learning, bringing up children, and cultural and social engagement', and of certain kinds of 'nonmarketable forms of work', it is work in the sense of traditional paid jobs which alone can guarantee 'gesellschaftlichen Zusammenhang [social cohesion]' and 'die Entfaltung der Persönlichkeit, wenn es um ein selbstbestimmtes Leben geht [the unfolding of the personality in a self-determined life]'. Indeed, says Klima, 'nonmarketable work' could be incorporated in the economy and lead to ten thousands of new jobs! A speech by Harriet Harman, quoted in Fairclough (2000: 57), voices much the same sentiment:

Work is the only route to sustained financial independence. But it is also much more. Work is not just about earning a living. It is a way of life ... Works helps to fulfill our aspirations - it is the key to independence, self-respect and opportunities for advancement ... Work brings a sense of order that is missing from the lives of many unemployed young men.

However, in Britain equal emphasis is placed on the economic benefits of full employment, whereas in Klima's speech, and in most of the Austrian material we have looked at, this aspect is comparatively downplayed in favor of more traditional political-cum-ideological arguments and less explicit reference to the link between government and business. After all, Klima's speech must aim to persuade the trade unions and the workers.

It might be important, at this point to digress shortly and explain some of the background of the famous 'Austrian Social Partnership', which was founded after the Second World War to moderate the main conflict of 
modern societies: that between business and labor, between employers and employees (see Pelinka 1998: 139-142). From the very beginning, even the conservative party, the ÖVP (or Peoples Party) agreed that the employers had to exercise self-restraint. Moderation would be in their own interest. Strikes and conflicts would be prevented. The model was built on compromise, so as to avoid the big conflicts, even civil war, which had characterized pre-Second World War Austria. The main characteristics of the Austrian model can be summarized in five points (see Pelinka 1998: 150-151):

1. Duopoly: Negotiating power should be reduced to two voices, the trade unions and the employers.

2. Centralization: Decisions are made at the national level.

3. Hierarchy: Internal discipline was demanded and respected.

4. Informality: Many decisions were less than transparent and were made behind closed doors.

5. Introversion: Each side excluded options which would be unacceptable to the other.

This kind of consensus was a guarantee for a very peaceful development, on the one hand, and for opacity on the other hand. Much of the populist rhetoric in recent years attacked this system because of its opaque negotiations and bargaining. Even before the great coalition ended with the new government in February 2000, attempts to change this system had started but were unsuccessful because of the stability and inertia of both sides. Neoliberal economics, now adopted by the new government, tries to establish a new system, and social conflicts are now on the agenda (see also Talos 1993).

Coming back to our data, here, for instance, is the beginning of Labour's Green Paper on welfare reform, published around the same time as the Budget Speech we discussed earlier:

The Government's aim is to rebuild the welfare state around work. The skills and energies of the workforce are the UK's biggest economic asset. And for both individuals and families, paid work is the most secure means of averting poverty and dependence. (quoted in Fairclough 2000:135)

By contrast, the opening of Klima's speech sounds more like a manifesto than a modern policy document. He is 'selling' the new policies in traditional rhetoric:

Hier und heute wird Zukunft gestaltet. Wir wollen dieses Land verändern. Wir wollen es mit sozialer Verantwortung modernisieren. Wir wollen Politik machen fur ein neues sozialdemokratisches Jahrhundert. [Here and now the future is being created. We want to change this country. We want to modernize it with a sense 
of social responsibility. We want to create a politics for a new social democratic century.] (Manuscript from the Austrian Chancellery, 30 October 1998)

As in New Labour Britain, and as stressed in the Essen summit conclusions, one of the keys to 'new full employment is education and training'. Through good education and lifelong learning people will acquire and continue to develop the skills and qualifications that make them self-reliant, rather than dependent on government handouts. Security, in the new social democracy, must stem from 'trust in one's own skills and qualifications'.

In contrast to the Chancellor's Budget Speech, however, Klima's speech contains few specifics. Tax reforms are announced, but in a vague way ('Steuerreform, mit der der Faktor Arbeit entlastet wird [tax reforms that take the burden off the work factor]'). Agent deletion is the norm and the speech does not display the complex and varied modes of reference to the Government and the unemployed that characterized the British Budget Speech. The workers are not categorized, but simply referred to as Menschen 'people', except where the speech refers to the past, when workers were Nomaden 'nomads', Tagelöhner, die am Rand der Gesellschaft stehen 'casual labor on the edge of society', and Arbeitsnehmer 'employees'. The trade unions and their role are mentioned only once, when 'ein starkes Miteinander von SPÖ und Gewerkschaften [a strong coming together of the SPÖ and the trade unions]' is proposed. 'Our' proposed actions are central, where 'we' are the members of the SPÖ. These actions are, as we already indicated, much the same as those which were proposed in the UK at the same time. But for the reasons mentioned above, in the Austrian discourse the accent lies less on economic, and more on political/ideological legitimation. Hence the contradictions are starker and manifest the difficulties facing left-wing governments trying to pursue neoliberal policies. The same document acknowledges the value of unpaid work and proposes to change it into paid work. The same document stresses the security of traditional jobs and acknowledges the value of alternating periods of employment with other activities such as learning, bringing up children, and 'personal and cultural engagement' - without acknowledging the dangers of casualization and of creating new kinds of 'nomads' and 'casual workers on the edge of society'. Compared to the UK Budget Speech, the language of this document is a great deal more abstract, and hence a great deal more able to hide the ideological fault lines. To a large extent this is due to the generic differences between the two documents, but the different political traditions and contemporary political climates of the two countries also play a role. When, in the next section, we look at another document, we 
will be able to compare Austrian and UK practices, rather than legitimatory discourses.

\section{Austrian un/employment discourses: Government press releases and their take up in the press}

On 28 October 1998, two days before the speech discussed in the previous section, the Austrian Government issued a press release to announce the second Lehrlingsoffensive. This document outlines how the politics of 'new full employment' was in fact to be realized.

As in the UK Budget Speech, the key represented participants are the Government, the employers and the unemployed. The Government is personalized in the persons of Sozialministerin Lore Hostasch 'Minister of Social Affairs, Lore Hostasch' and Wirtschaftsminister Hannes Farnleiter 'Minister of Economic Affairs, Hannes Farnleiter'. However, while these two Ministers are represented as responsible for speech acts (such as erklären 'to explain', erläutern 'to clarify', Detailergebnisse skizzieren 'to sketch detailed results', Ergebnisse zusammenfassen 'to summarize results', etc.), when it comes to the actions that will realize the Lehrlingsoffensive, passive constructions and agent deletions are preferred (e.g., Über 2500 Betriebe wurden telefonisch beraten 'more than 2500 companies were given advice by telephone'). As a result it is not always clear whether the agent responsible for a certain action is the Government or business, as for example in Es wurden 1500 Lehrstellen zusätzlich angeboten '1500 additional apprenticeship positions were offered'. The employers are institutionalized, referred to as 'companies', 'businesses', etc., whereas in the UK they were personalized, referred to as 'employers', etc. And the unemployed are variously called Lehrstellensuchende 'apprenticeship seekers', Schulabgänger 'school leavers', Jugend 'youth', Jugendliche 'the young', Lehrlinge 'apprentices', but never 'unemployed'. After all, the document aims to assert 'daß jeder Jugendliche die Chance auf eine qualifizierte Ausbildung bekomme [that every young person will be given a chance to obtain a qualification]' and that 'jedem Schulabgänger eine Lehrstelle oder eine Überbrückungshilfe anbieten ... [every school leaver will either be offered an apprenticeship position or bridging help ...]'note the way in which 'bridging help' (i.e., pre-apprenticeship training) and apprenticeships are fused and confused in such expressions.

What precisely are the ways in which the policy of "new full employment' is realized here, at least insofar as youth employment is concerned? In the case of the first Lehrlingsoffensive this includes visiting and telephoning employers to advise them of the Government's incentives for taking on apprentices; providing a hotline for young people; registering 
those seeking apprenticeship positions; and offering apprenticeships. Overall these actions are, as in the UK, 'managing' actions. The Government coaxes and helps other people to do things, rather than doing things directly. Yet employers and unemployed are represented as relatively passive beneficiaries of Government initiatives (e.g., Unternehmen ... wurden betreut in Betriebsbesuchen 'Employers ... are looked after by means of company visits'). Often their actions are nominalized so that agency is backgrounded (e.g., Die Lehrlingshotline verzeichnete 2.111 Anrufe 'The apprentice hotline registered 2,111 calls'). The act of looking for an apprenticeship forms the only exception to this.

The description of the second Lehrlingsoffensive displays the same pattern. 'Ein umfangreiches Netz an Angeboten wird geschaffen [An extensive net of offers is created]'-one may ask, by whom? Or, again, 'Unternehmen werden angeschrieben und ... informiert [companies are written to and ... informed]', 'ein Call-Center wurde eingerichtet [a call center was set up]'. But here the actions of the Government are also formulated in more abstract and ideological terms, with the phrase 'a chance for work' again central: der Jugend hervorragende Chancen bieten 'offer the young excellent chances', sicherstellen, dass jeder Jugendliche die Chance auf eine qualifizierte Ausbildung bekomme 'ensure that every young person has the chance to obtain professional training'. This message, in which, as mentioned, education and training (which can be offered by the Government) and work (which cannot) are fused and confused, is repeated over and over. Again, legitimatory devices are used. The veiling of the actual agents, the use of the term Menschen 'people' and the importance of work offer the possibility of compatibility with traditional social democratic ideologies.

On the day this Government announcement was released, Der Standard published a short article which did not yet make reference to the announcement, but seemed to rely on another press release, issued by the City of Vienna. At first sight the article resembles the press release we have just discussed. The only participants introduced by name are Vienna's Sozialstadträtin 'City Councillor for Social Affairs' Grete Laska and Wirtschaftskammerpräsident 'President of the Board of Trade' Walter Nettig, and the only actions explicitly connected to their names are all speech acts, such as verkünden 'announce', hinzufügen 'add', etc. Actual government actions are passivized and delete the agent (e.g., 825 Ausbildungsplätze wurden geschaffen '825 training places were created'), though not to the same degree as in the press release. The paper also institutionalizes the Government (Stadt Wien und Wirtschaftskammer haben sich auf ein Auffangnetz fur Schulabgänger geeinigt 'The City of Vienna and the Board of Trade have agreed on a safety net for school 
leavers') and activates the 'school leavers': die Jugendlichen können dort ihre Ausbildung beginnen 'young people can begin their training there'.

Overall there is less concentration here on the apprenticeships, and much more on 'post school' and 'pre-apprenticeship' education, both by providing details, such as that the 'Lehrlingsstiftungen und Lehrgänge [apprenticeship foundations/grants and courses]' prepare the young unemployed for the 'Übertritt in die Lehre [transition to apprenticeship] and remedy 'schulische Defizite [educational deficits]', but above all by legitimizing them on the grounds of what Levitas (1998) has called a 'moral underclass' discourse, a discourse which sees the problem as stemming from deficiencies in the culture of an 'underclass'. Klima's speech did not use such a discourse and preferred a social integrationist one, a discourse based on the idea that social integration rests on full employment and getting people back into work. On the other hand, the 'moral underclass' discourse did appear in UK papers such as the Sun. In Der Standard it not only emerges in the term 'educational deficits' but also in these quotes from Nettig and Laska:

Denn, so Wiens Wirtschaftskammerpräsident Walter Nettig, Unternehmer klagten zusehends, das Jugendliche 'zu unreif' für den Eintritt in der Lehre seien. Dem fügte Laska hinzu: Es gebe ein 'eklatantes Informationsdefizit' bei den Eltern. [According to Vienna's Board of Trade President Walter Nettig, employers complain that the young are 'too immature' to enter into apprenticeship. Laska added, 'There is a spectacular "information deficit" on the part of the parents'.] (Der Standard, 28 October 1998, p. 11)

Later in the same piece it is again the young unemployed themselves who are blamed for the remaining unemployment and the relative failure of the Government initiatives:

Das Interesse der Jugendliche konzentriere sich aber auf ganz wenige Berufe. So seien in den neugeschaffenen Lehrberufen ... noch Plätze frei. [Young people's interest centers only on relatively few jobs. In the newly created apprenticeship occupations ... there are still places available.] (Der Standard, 28 October 1998, p. 11)

There is no mention, of course, of the conditions of work in these 'newly created apprenticeship occupations'.

The next day's Standard reports the announcement of the second Lehrlingsoffensive. Again the article resembles the press release. Ostensibly it passes on information from Social Affairs Minister, Lore Hostasch, and Economic Affairs Minister, Hannes Farnleiter. The two are mentioned by name and figure prominently as the performers of speech acts such as erklären 'to clarify', glauben 'to believe', zeigen 'to show', etc. The actual Government actions are once again impersonalized: Eine Hotline wurde 
eingerichtet 'A hotline was set up', Anreize für die Betriebe sollen der Offensive Schubkraft verleihen 'incentives for companies should lend the scheme driving force', although here more institutionalized and instrumentalized actions occur, as well as nominalized references to Government actions, e.g., Die zweite Lehrlingsoffensive setzt auf Beratung und Information 'The second apprenticeship scheme focuses on advice and information'. All this is different to Klima's speech, and a great deal more formal, though less abstract.

As in the press release, the unemployed tend to be functionalized, e.g., as Schulabgänger 'school leavers', Jugendliche 'the young', or Lehrlinge 'apprentices'. In this article, however, the employers are also functionalized in references to 'Freiberufler, wie Notare oder Anwälte [independent professionals such as accountants and lawyers]', or even mentioned by name (e.g., Wirtschaftsanwalt ['solicitor'] Christian Winternitz). This time, rather than using the 'moral underclass' discourse, the paper adds legitimation of the Government's actions by quoting an employer who has decided to take on an apprentice.

The Government actions are again divided according to the two 'apprenticeship attacks', exactly as in the press release. In the first phase apprenticeships were negotiated; an Auffangnetz 'safety net' in the form of 'apprenticeship training courses' and 'apprenticeship grants' was established, providing a year of Berufsvorbereitung 'job preparation' and two billion shillings were budgeted for the purpose. The second Lehrlingsoffensive would focus on advice and information. A hotline would be established, and incentives would be provided for companies involved in the new Lehrberufen 'apprenticeship occupations', e.g., Schutzalter-senkungen 'lowering of the minimum age' and a tax-free contribution for each apprentice. As before, the Government actions are also reworded in more abstract ways, adding an element of legitimation, e.g., Jeder Jugendliche soll eine Chance und Perspektive haben 'every young person should have a chance and perspective'.

However, in this article Der Standard represents the activities of the young unemployed more positively than it did a day before. Now, they 'find connection to the world of work', 'find employment in the new apprenticeship occupations', and 'profit from the boom in the service sector'. The employers, too, are not just represented as the target of Government initiatives, but given a more active role:

Freiberufler, wie Notare oder Anwälte, müssen jetzt keinen Befähigungsnachweis zur Lehrlingsausbildung mehr erbringen. Deshalb hat auch der Wirtschaftsanwalt Christian Winternitz erstmals einen Lehrling eingestellt, 'Die alte Regelung hat mich davon abgehalten, einen Bürokaufmann-Lehrling zu nehmen', erklärt 
Winternitz. [Independent professionals such as accountants and lawyers no longer require a certificate of competence for training apprentices. As a result solicitor Christian Winternitz has taken on an apprentice for the first time. 'The old rules stopped me from taking on an apprentice clerk', said Winternitz.] (Der Standard, 29 October 1998, p. 7)

Clearly the inclusion of this quote serves to lend credibility to the Government's initiatives, because it shows that it makes economic sense for employers to hire more people.

Interestingly, the article begins and ends with figures. Initially it deplores the relative lack of success of the first Lehrlingsoffensive: 'Die Aussichten sind nicht rosig [the prospects are not rosy]'. But after the positive quote from Winternitz the solicitor, the Government's glowing references to the unemployment statistics are allowed to stand unchallenged as the conclusion to the article, under the subheading 'Europaweit Spitze [Ahead of the rest of Europe]', as if the article has already forgotten how it began before it ends.

Clearly, these newspaper reports follow the Government views closely, if not always accurately, when it comes to reporting past or future actions. But they also add one or both of the following: a mild critique (of figures rather than substance), and, just like the British newspapers, their own legitimizing discourse or point of view. That such discourses can differ from day to day experiences must make it difficult for the public to reach a clear understanding of the issues involved.

In all of this there is little left of the issues raised in Klima's speech (e.g., that of 'nonmarketable work'). The legitimacy of a policy of 'full employment' is taken for granted. Education and work become fused and confused. And the fact that in a period of increasingly global economics such problems can no longer be addressed at the level of the nation state is not even mentioned.

\section{Austrian un/employment discourses: Klima meets the employers and the unemployed}

Seven months into the second Lehrlingsoffensive, Klima addressed a meeting of employers. Here he produced a much more elaborate and quite different view of the relation between government and industry. The 'new full employment' is represented as resulting from the employers' initiatives, in which the Government has at best played a supporting role. The employers, rather than the Government, are represented as the agents of such actions as Ausbildungsplätze schaffen 'to create training places', neue Lehrlinge aufnehmen 'to take on new apprentices', etc. Politics is represented as having merely provided the conditions for this. On 
this occasion, then, Klima switches to a different political and rhetorical strategy. The employers receive positive feedback. The changes in Klima's rhetoric can be seen as a populist strategy: he 'markets' his program in whatever way is most appropriate to the given context.

The role of the employers here is not only represented as an active one, but also as governed by moral rather than economic motives-fortunately these moral motives are not inimical to economic ones. Klima praises employers for their Weitblick 'vision' and for the sense of responsibility out of which they 'give youth a chance'. Again work is represented as a 'right', as in dem Grundrecht eines Jugendlichen auf einen fertig erlernten Beruf 'the fundamental right of a young person to the comprehensive mastery of a trade'. This phrase Klima puts in the mouth of a 'office machine repairman' who took an apprentice and wrote to the Chancellor, 'Wir bilden Lehrlinge aus, weil wir jungen Leuten die Chance geben wollen [We train apprentices because we want to give young people a chance]'. Klima calls him an example of 'Austrian enterprise culture'. The financial incentives provided by the Government - tax free contribution for each apprentice; dispensation of the obligation to contribute to the employee's social security and health insurance, and so on-are left out on this occasion. And where, in this world of 'office machine repairers' and solicitors who take on single apprentices, are the large corporations? Presumably in countries where even lower wages can be paid.

Comparing Klima's two speeches clearly shows how the same practices may be recontextualized quite differently when different participants are addressed. Looking now at a further speech, in which Klima addresses the teachers and students at one of the newly created pre-apprenticeship training institutions in Kärnten a month earlier bears this out, and further demonstrates the ways in which Klima changes his arguments and legitimations as he moves from audience to audience.

While in this speech he refers to the young unemployed in much the same way as in his other speeches, and with the same confusion between Lehrstellensuchenden 'those seeking apprenticeships' and Lehrlingen 'apprentices', the employers are entirely absent from this speech. This time the Government is the single agent of the progress made towards 'new full employment'. The speech culminates in an extensive list of Government achievements:

Vieles haben wir bereits in Bewegung gesetzt

- Wir haben neue Lehrberufe geschaffen - dort arbeiten bereits 1966 Lehrlinge

- Wir haben die Berufsreifeprüfung eingeführt

- Wir haben Änderungen im Berufsausbildungsgesetz vorgenommen

- Wir haben die Kosten fur Lehrausbildung deutlich gesenkt

- Wir haben eine enorme Summe von AMS-Fördermitteln eingesetzt 
- Und wir haben ein Auffangnetz fur 4000 Jugendliche geschaffen

[We have already achieved a great deal

- We have created new types of apprenticeship - 1966 apprentices already work in these

- We have introduced a job maturity test

- We have undertaken changes in the vocational training law

- We have significantly lowered the costs of training apprentices

- We have made an enormous amount of employment market services funding available

- And we have created a safety net for 4000 young people] (Manuscript from the Austrian Chancellery, 30 September 1998)

All this is then rephrased in ways which, once again, adduce the by now familiar ideological themes of the 'right to work' and of work as the only road to 'personal fulfillment', 'self-reliance' and 'independence', e.g., den Jugendlichen wurden Chancen eröffnet zu einem selbsbestimmten und erfolgreichen Leben 'the chance for a self-determined and successful life is opened up for young people', Chancen müssen allen offenstehen 'Chances must be available to all'. Though less prominently, the economic theme also makes an appearance: Eine gute Ausbildung der Jugend ist das sicherste Fundament für eine leistungsstarke Wirtschaft 'A good education for the young is the surest foundation for a strong economy'.

Politics, Klima tells the young unemployed in the school in which they are being 'prepared for apprenticeship', 'is not powerless'. It 'takes people's problems seriously and helps solve them'. A responsible, human approach translated into powerful action-how different from the more humble stance Klima took when addressing the employers.

\section{Conclusion}

The precise and detailed analysis of the three settings and the discourses in these settings (among party members, employers, or unemployed) in Austria makes the ideological and linguistic/grammatical recontextualization explicit: in times of social and political change, economic changes have to be 'marketed' to various electorates with very different arguments and in very different ideological guises. At the party meeting, traditional socialist slogans are invoked; for employers, the role of the state is downplayed; when meeting the young unemployed, their equal chances and rights are stressed. Grammatical variation (who are the agents; how, if at all, are they referred to; what are the legitimation devices used?) is significant and apparent. Nevertheless, the underlying message is clear and relates to the political functions found in our study (Muntigl et al. 2000) mentioned at the outset. Globalization is to be seen as natural, necessary, and good. 
Although the context of our earlier study of un/employment discourses in the UK was a little different, focusing on the Chancellor's Budget Speech and the ways in which it was taken up in a range of newspapers, comparisons are possible. Both studies deal with left-wing governments who, in a European context, are proposing economic changes and developing or adapting legitimation devices and politicial rhetoric to this end. Both seek to veil continuing unemployment, and are particularly concerned about unemployment among the young. The measures taken are similar. And in both cases unemployment is rhetorically eliminated: there are no unemployed, only people with an offer of training, an offer of employment, or an offer of counseling. The only difference is the greater emphasis in Britain (especially in the press) on the 'moral underclass' discourse and its mythologies of 'lazy dole scroungers' living off state handouts. In Austria, the politicians seem less concerned to assure taxpayers that their money is not used in this way, and it is also a less prominent theme in the press reports we have looked at (although it does turn up). The other difference is that economic issues are more foregrounded in the UK, while traditional political-cum-ideological issues are foregrounded in the Austrian discourses. But these are differences in discursive accent. The drift of both the measures taken and the rhetoric with which they are marketed is quite similar in the two cases - and accords quite well with the Essen summit recommendations we discussed in the earlier part of this article.

As already mentioned, Austrian politics have changed significantly. The new right-wing government in place since 4 February 2000 openly endorses neoliberal policies. The electoral loss of the Social Democratic party and Chancellor Klima on 3 October 1999 are certainly not only due to the policies discussed here (see Scharsach 2000) but to many other factors; however, the difficulties involved in changing the old and static Austrian economic system were certainly an important factor. Chancellor Klima's populist attempts to sell neoliberal policies with traditional slogans and socialist ideologies could be said to have failed.

\section{Notes}

1. In this section, we rely largely on and summarize some arguments of Gilbert Weiss (2000a, 2000b). Moreover, we would like to thank Gilbert Weiss for his important comments on our article.

2. The percentage of unemployed in the EU differs widely with regard to (a) individual member states, with, for instance 20.8 percent in Spain (the highest rate) and 2.6 percent in Luxembourg (the lowest) in 1997, and (b) individual regions (e.g., Bavaria and RhôneAlpes showing the lowest rates of the Union versus southern Italy, southern France, and southeast England exhibiting the highest). 
3. Both of the anonymous reviewers of this article expressed surprise that we should take Klima to task (as they saw it) for addressing different audiences in different ways. However, in Austria political life is (still?) far more ideologically oriented and far less governed by pragmatic prerogatives than, say, in the UK. What caused Blair to win caused Klima's loss (and Haider's victory). Neither the 'old' left, nor the 'far' right in the UK possess the force which they have in Austria, where many sectors of society are politicized in ways that have no equivalent in the UK and where the influence of the trade unions on the left is still much greater. The non-Austrian author of this article also failed to understand these differences at first, and assumed similarity where none exists. The issue is important. While in one sense the UK and Austria are spurred on by EU policy to implement the same type of measures, in another sense they do so in quite distinct ways, and with quite distinct accents, of which the emphasis on the traditional notion of the 'apprentice' is only one.

\section{References}

Bauman, Z. (1999). In Search of Politics. London: Routledge.

Billig, M. (1997). Banal Nationalism. London: Routledge.

European Commission (1994). White Paper on Growth, Competitiveness and Employment. Brussels: European Commission.

-(1997). Jobs Summit. Three Documents Adopted by the European Commission on 1st October 1997. Brussels: European Commission.

Fairclough, N. (2000). New Labour, New Language? London: Routledge.

Joint Employment Report (1998). European Union: Brussels.

Levitas, R. (1998). The Inclusive Society? Social Exclusion and New Labor. London: Macmillan.

Martin, J. R. (1992). English Text: System and Structure. Amsterdam: Benjamins.

Muntigl, P., Weiss, G., and Wodak, R. (2000). European Discourses on Un/employment. An Interdisciplinary Approach to Employment Policy-Making and Organizational Change. Amsterdam: Benjamins.

Pelinka, A. (1998). Austria. Out of the Shadow of the Past. Boulder, CO: Westview Press.

Scharsach, H. (2000). Die rechte Versuchung. Hamburg: Fischer.

Sennett, R. (1998). Der flexible Mensch. Die Kultur des neuen Kapitalismus. Berlin: Berlin Verlag.

Straehle, C., Weiss, G., Wodak, R., Muntigl, P., and Sedlak, M. (1999). Struggle as metaphor in European Union Discourses on unemployment. Discourse and Society 10 (1): $67-100$.

Talos, E. (1993). Sozialpartnerschaft. Kontinuität und Wandel eines Modells. Vienna: Böhlau. Thurow, L. (1996). The Future of Capitalism. How Today's Economic Forces Shape Tomorrow's World. New York: Penguin.

van Leeuwen, T. (1996). The representation of social actors. In Texts and PracticesReadings in Critical Discourse Analysis, C. Rosa Caldas-Coulthard and M. Coulthard (eds.), 31-72. London: Routledge.

- (1999). Discourses of unemployment in New Labour Britain. In Challenges in a Changing World - Issues in Critical Discourse Analysis, R. Wodak and C. Ludwig (eds.). Vienna: Passagen Verlag.

van Leeuwen, T. and Wodak, R. (1999). Legitimising immigration control: A discoursehistorical analysis. Discourse Studies 1 (1): 83-119. 
Weiss, G. (2000a). Labour markets, unemployment and the rhetoric of globalization. In European Discourses on Un/employment. An Interdisciplinary Approach to Employment Policy-Making and Organizational Change, P. Muntigl, G. Weiss, and R. Wodak (eds.), 27-50. Amsterdam: Benjamins.

- (2000b). Researching the European Union. Data and Ethnography. In European Discourses on Un/employment. An Interdisciplinary Approach to Employment PolicyMaking and Organizational Change, P. Muntigl, G. Weiss, and R. Wodak (eds.), 51-73. Amsterdam: Benjamins.

Weiss, G. and Wodak, R. (2000a). European Union discourses on employment. Strategies of depolitizing and ideologizing employment policies. Concepts and Transformation 5 (1): $29-42$.

- (2000b). Debating Europe. Globalisation rhetoric and European Union employment policies. In An Anthropology of the European Union: Building, Imagining and Experiencing the New Europe, Irène Bellier and Thomas M. Wilson (eds.), 75-91. Oxford/New York: Berg.

Wodak, R. (2000a). From conflict to consensus? The co-construction of a policy paper. In European Discourses on Un/employment. An Interdisciplinary Approach to Employment Policy-Making and Organizational Change, P. Muntigl, G. Weiss, and R. Wodak (eds.), 73-114. Amsterdam: Benjamins.

- (2000b). Recontextualization and the transformation of meanings: A critical discourse analysis of decisionmaking in EU-meetings about employment policies. In Discourse and Social Life, S. Sarangi and M. Coulthard (eds.), 185-206. Harlow: Pearson Education.

- (in print). Changing Organizations. Europe in the Search of Multiple Identities.

Wodak, R., de Cillia, R., Reisigl, M., and Liebhart, K. (1999). The Discursive Construction of National Identity. Edinburgh: Edinburgh University Press.

Ruth Wodak is Professor of Applied Linguistics at the University of Vienna and Director of the Research Centre for Discourse, Politics, Identity at the Austrian Academy of Sciences. Her recent books are Discourse and Discrimination (with Martin Reisigl, Routledge 2001), Methods of Critical Discourse Analysis (with Michael Meyer, Sage 2001), and European Union Discourses on Un/employment (with Peter Muntigl and Gilbert Weiss, Benjamins 2000). Address for correspondence: Austrian Academy of Sciences, Strohgasse 45/8, A-1030 Vienna, Austria. E-mail: < ruth.wodak@oeaw.ac.at>.

Theo van Leeuwen is Professor of Language and Communication at Cardiff University. He has published in the areas of critical discourse analysis, social semiotics and multimodality. His most recent books are Speech, Music, Sound (Macmillan, 1999), Multimodal Discourse (with Gunther Kress, Arnold 2001), and the edited volume Handbook of Visual Analysis (with Carey Jewitt, Sage 2000). Address for correspondence: Centre for Language and Communication Research, Cardiff University, PO Box 94, Cardiff CF10 3XB, Wales, UK. E-mail: < vanleeuwent@cardiff.ac.uk>. 